\title{
THE MAPPING POLITICAL OF IDENTITY IN LOCAL ELECTION OF NORTH MALUKU 2013
}

\section{Gustiana A. Kambo}

Ilmu Politik Universitas Hasanuddin

Email: gustianakambo@yahoo.com

DOI: https://doi.org/10.18196/jgpp.5294

Article Info

Article history:

Received 12 Mar 2018

Revised 21 May 2018

Accepted 4 Jun 2018

\section{Keywords:}

Identity, political identity, ethnic idenitity, religion identity.

\section{ABSTRACT}

The interpretation of identity politics as a source and political means in the implementation of the election is well recognized by the candidates for regional head. In the Local Election North Maluku 2013 identity politics occurs at the practical level that is used as a tool-manipulation tool to raise political power to achieve an interest. This study looks at how the mapping of identity politics ethnic and religious backgrounds that occurred in North Maluku election in 2013. This research uses qualitative research methods with the type of descriptive analysis research. This research data is obtained from interviews and articles related to research conducted. The results of this study indicate that in the election there is a mapping of identity politics based on ethnic and religious identity. Ethnic identity and religious identity become a tool for raising political power to each candidate of regional head, so that the candidate of the head of region only excels in ethnic or religious base areas..

\section{ABSTRAK}

Interpretasi politik identitas sebagai sumber dan sarana politik dalam pelaksanaan pemilihan umum diakui dengan baik oleh calon kepala daerah. Dalam Pemilu Lokal Maluku Utara 2013 politik identitas terjadi pada tingkat praktis yang digunakan sebagai alat manipulasi-alat untuk meningkatkan kekuatan politik untuk mencapai suatu kepentingan. Penelitian ini melihat bagaimana pemetaan identitas politik etnis dan latar belakang agama yang terjadi dalam pemilihan Maluku Utara pada tahun 2013. Penelitian ini menggunakan metode penelitian kualitatif dengan jenis penelitian analisis deskriptif. Data penelitian ini diperoleh dari wawancara dan artikel yang berkaitan dengan penelitian yang dilakukan. Hasil penelitian ini menunjukkan bahwa dalam pemilihan ada pemetaan politik identitas berdasarkan identitas etnis dan agama. Identitas etnik dan identitas agama menjadi alat untuk meningkatkan kekuatan politik bagi masing-masing calon kepala daerah, sehingga calon kepala daerah hanya unggul di daerah basis etnis atau agama. 


\section{INTRODUCTION}

Political Phenomenon The identity that occurred in North Maluku became one of the interesting discussions in the election. The growing number of ethnicity to occupy the number one seat in the Province has had an impact on the people of North Maluku in selecting their future leaders. Of course social background factors, capital and ethnic factors to benchmark the community in assessing and voting their choice of candidates. With the outcome of the vote count by the North Maluku Provincial Election Commission it is clear that Ahmad Hidayat Mus- Hasan Prayer becomes the governor and the elected deputy governor in this first round - the second round will be held as the result of the highest vote achievement is not up to $30 \%$ who are able to win in one district city and four districts, the Sanana ethnic origin region of Sula district is also included in its winning area. Identity politics is expected to start influencing the results of the North Maluku election in 2013.

The victories of several pairs of candidates for governors and deputy governors of their respective ethnic origins signal that more and more ethnics participate in the political process and begin to show their ethnic identity. Their existence began to be exposed through their respective 'them' candidates who are expected to bring better change to North Maluku, especially their ethnicity. Their existence by embracing people of ethnic origin and exposing their ethnic identity in the political process becomes an endeavor for them. 
The existence of ethnic voting began to spread. The existence of ethnic voting occurs for a number of reasons. First voters vote by ethnicity because they are confident that their candidates will protectbecome their patrons. Second, they choose their 'candidates' because they have the same political and economic interests. Third, voters choose their 'candidates' to better show their ethnic expression and become one of the psychological affirmations of group identity. Choosing by ethnicity is one of the most dangerous effects of identity politics. If elections made to ethnically divided society will result in census elections away from democracy. inter-ethnic conflict becomes inevitable especially if issues, prejudices and stereotypes begin to color the election. This is certainly very worrying to be able to create a peaceful election. Based on the things that have been described above, the authors are interested in conducting research on identity politics with the title, "The Mapping Political of Identity in Local Election of North Maluku year 2013."

\section{Research Question}

Based on the problems that have been described earlier then the formulation of the problem in this research is how the mapping of political of identity in the North Maluku local election in 2013?

\section{Research Purpose}

This study aims to determine the influence and the impact of identity politics with ethnic identity and religion identity in the North Maluku local election in 2013. 


\section{LITERATURE REVIEW}

\section{Political of Identity}

Political Identity refers to the political mechanisms of organizing identity (both political identity and social identity) as a source and a political means. The meaning that the politics of identity as a source and political means in the struggle for the struggle for political power is very possible and increasingly surfaced in the daily practice of politics. Therefore scientists working in the discourse of identity politics try their best to try to reinterpret in a very simple and operational logic. Agnes Heller defines identity politics as a political movement whose focus of attention is difference as a major political category. Geertz went a step further in looking at the identity politics that took place on a practical level. Identity politics is usually used as a means of manipulating tools to raise politics for economic and political purposes. However, on the other hand, Geertz's argument declines in interpretation by saying that, in identity politics, of course, tribal ties play an important role, it becomes a potential cultural symbol and a source of power for political action. This understanding has implications for the tendency to: Firstly, want to gain recognition and equal treatment or basic rights as a human being both political, economic and socio-cultural. Second, in order to maintain and preserve the cultural values that characterize the group concerned. Finally, strong loyalty to the ethnistas it has. 


\section{1). Ethnic of Identity}

Ethnicity is a type of group-based social identities, such as other group-based identities (such as classes and clans). But ethnicity has a powerful special effect on political behavior in the late twentieth and early twenty-first centuries. Donald Horowitz refers to the concept of ethnicity as a broad term that encompasses different groups based on color, language and religion; which includes 'tribe', 'race', 'nationality' and 'caste'. In general, the earliest academic conversations about ethnic identity formation are characterized by two major debates or so-called primordial perspectives and situational perspectives.

The first approach is primordialism that generally views ethnic identity as "innate" and natural (natural) in certain contexts. Anthony Smith (1986) identifies various variations of primordialism, including primordialism and primordialism of kinship. Essential primordialism says that ethnicity is a fact of natural biology and therefore ethnicity precedes human society. This approach has a relatively small impact on academic thinking, although it is politically highlighted by racial supremacists from time to time.

\section{2). Ethnic Voting}

A common theme in studying voting in a new democracy is the persistence of ethnic relevance in the developing world, where ethnic ties based on kinship and family, language and dialect, tribal 
126 customs and local communities, in addition to shared religious beliefs, play an important role in the party -political parties. Ethnic voting is often considered a product of patronage democracy, in which the State monopolizes access to work and administrative resources. These countries seek legitimacy and population support, using a selective targeting strategy, in which particular groups are selected to receive the greatest benefits from State resources. Therefore, voting based on certain ethnic lines will partially benefit from patronage. In this way, ethnic identity offers quick information, which informs voters that voting for ethnic or ethnic candidates will benefit voters rather than voting for candidates or parties from other ethnic groups.

Voters are confident that the benefits will be more likely to be achieved by demonstrating solidarity with the community. In other words, they realize that only members of their own ethnic group can defend the interests of the ethnic group as a whole, and that members of other ethnic groups will certainly not defend them. Ethnic voting in this study will be used as an indicator in mapping the identity politics that occurred in the North Maluku local election in 2013. The tendency of voters to vote based on ethnicity and religion can be known using the concept of ethnic voting. The ethnic groups in North Maluku are very diverse, ranging from ethnic majority, to minority. Especially for ethnic majority will be more likely to do this ethnic voting, because this ethnic majority will certainly show their identity and because the majority of their social 
interests are also large-scale that requires leaders who can accommodate their interests, namely leaders of their ethnic own.

\section{Local Election}

Elections are an important thing in public life, through elections the people choose their representatives to sit in parliament and in government structures. Elections in a general election system (elections) constitute an important institutional decision for countries that seek to uphold the civilization and qualities of the political system.

The general election of regional head or often abbreviated as Pemilukada (local election) is a political process in an effort to improve democratization at the local level where the people are given the widest opportunity to choose the regional head according to their choice. Article 1 of the Regulation of the Minister of Home Affairs concerning Guidelines for Local Government in the implementation of the election of regional head and deputy head of region paragraph 1 states that "Direct Regional Head Election is a series of activities in the election of regional head and deputy head of provincial and district / municipality". Local election Technically has a simpler electoral process than election. For example, if no candidate is able to get a 50 percent +1 vote, a candidate who gets votes over 25 percent can be considered a winner. Therefore, there is rarely a local election that uses a second round mechanism. However, in line with the amendment to the Law on Regional Government, from no. 22 of 
2004 became No. 12 in 2008 which raise the voting requirement from 25 percent to 30 percent, may allow some pilkada to be held to follow a second round mechanism which means that, if in the first round there is no candidate who gets the minimum vote determined, there will be a second round with the two participants pairs of candidates who get the most votes

\section{Framework}

The ethnic strength that each candidate muster in the implementation of the Governor Election is very strict, especially most of the ethnic groups in North Maluku have representatives for candidates for governor and vice governor. The author agrees with the statement of Agnes Heller and Donald J. Morowitz who states that the politics of identity interpreted as a political difference. The distinction between each ethnic contest in the elections makes this local election event a platform for certain ethnic groups to show their identity within the community.

This understanding has implications for the tendency to: Firstly, want to gain recognition and equal treatment or basic rights as a human being both political, economic and socio-cultural. Second, in order to maintain and preserve the cultural values that characterize the group concerned. Finally, strong loyalty to the ethnistas it has. In politics the identity of tribal ties has an important role, it becomes a potential cultural symbols and a source of power for political action, then in this research, the author tries to see the identity politics that occur in 
the elections through ethnicity and ethnic identity owned by each candidate governor and vice governor.

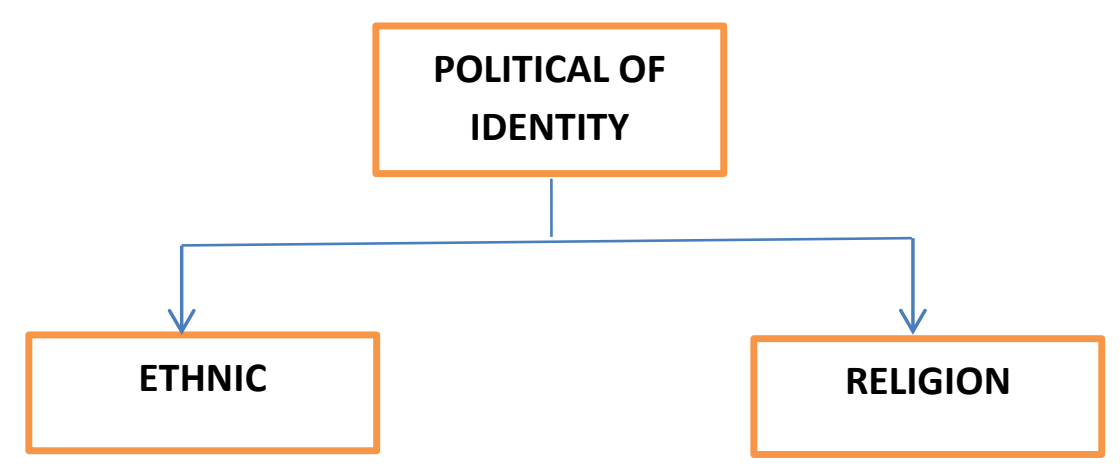

\section{DISCUSSION}

\section{Political of Identity Mapping}

\begin{tabular}{|l|l|l|l|l|l|l|l|l|l|}
\hline & Ternate & tidore & Halbar & Halut & Haltim & Halteng & Halsel & Sula & Morotai \\
\hline NHR-IA & 7756 & 6225 & 27654 & 7075 & 3528 & 3628 & 5024 & 1484 & 3644 \\
\hline MA-SH & 12.938 & 4010 & 3704 & 8508 & 2807 & 1417 & 13764 & 3066 & 3016 \\
\hline AHM-HD & 23.353 & 15579 & 10350 & 15118 & 10828 & 9237 & 24748 & 46874 & 7597 \\
\hline SA-BL & 32.856 & 11366 & 6702 & 4333 & 4627 & 3281 & 9006 & 2719 & 4356 \\
\hline AGK-MNT & 15.094 & 12240 & 3664 & 10226 & 7974 & 13747 & 50127 & 16039 & 4578 \\
\hline HN-MI & 2325 & 3395 & 7377 & 48117 & 8967 & 3276 & 6837 & 1320 & 6857 \\
\hline
\end{tabular}

\section{A. Identity of Ethnic}

Ethnic identity is the basis of the first mapping found in this study. According to Brubaker (1992) ethnic identity is one of the major political forces capable of generating mass political behavior. Geertz argues that ethnic identity is not necessarily linked to blood relations, but also to ethnic ties and group bonding and this is a 
natural process because racial and physical objective characteristics help form social bonds. Local election conducted in North Maluku on July 1, 2013 ago has obtained the following votes:

Their ethnic and social background proved to be a force in winning the election. Especially for the ethnic background of the couple is able to use their identity politics which refers to the political mechanisms of organizing the identity (both political identity and social identity) as a source and political means. The victories of several would-be Governors in their home regions such as Ahmad Hidayat Mus-Hasan Prayer in his area of Sanana, and Hein Namotemo and Malik Ibrahim in North Halmahera justify the Ethnic Voting theory expressed by Horowitz through expressing voting hyposthesis confirming that voters use voting express their identity as part of an ethnic group. The ethnic Voters from the Sulaindigenous Sula region known as the Sanana-and Tidore ethnic groups tend to show solidarity with the community. In other words, they realize that only people from their ethnic group can defend the interests of the ethnic group as a whole, so that ethnic voters will try to gather their "people" and reinvention, where ethnic Sanana or Tidore interact with people ethnic people who are located throughout North Maluku and remind them of the importance of group solidarity, the importance of selecting ethnic candidates to achieve group interests and verification of their identity in their social environment. 
Horowitzs's thoughts are similar to that of Van de Walfe who point out that only members of their own ethnic group can defend the interests of the ethnic group as a whole while other ethnic members certainly will not defend them. The multicultural ethnic Maluku culture still gives some restrictions on ethnicity, for example they still tend to choose leaders from the same region and ethnic as they are, still the term "your people" or "my people" which indicates whether they belong to the same or different ethnicity. The candidate pairs use their ethnic identity to be made as one means of building political power, this is an advantage gained by candidate pairs. As for ethnic voters this is an advantage for them, because if the candidates who come from their ethnic elected then their lives will be more prosperous and strengthening their ethnic identity will be increasingly recognized in their social environment. The determination of limits expressed by public figures on the differences between us and those above has a similar understanding to that described by Donald L. Morowitz where in the identity politics there will be a clear line to determine who will be included and who in rejects and giving a clear line that tends to be difficult to change even tend to be permanent.

\section{B. Identity of Religion}

For many people, religion is the foundation for selfknowledge and plays a major role in many human decisions. In many ways, religion always has and continues to have a very personal 
132 relationship with many people and hence religion can be used in many ways as a powerful motivator, not to mention the religion which is then used as a way of political activity.

Religion in use in political activities of course has its own goals and interests. The election of Governor who carried out in North Maluku has a political distinction based on the identity of Religion. As it is known that North Maluku is one of the multi ethnic and multi-religious provinces, there are even some areas that openly show the identity of the majority religion in the region. Political phenomenon of the difference that is based on the identity of this religion researchers get in the process of North Maluku election 2013. It can not be denied that North Maluku has a history of ethnic conflict and religious conflict leaving the impact of these conflicts in geographical or territorial form. Starting from the conflict between Islam and Christianity in Tobelo in 1998 until the ethnic conflict that occurred in Ternate in 2003 and then still have an impact on the election of Governor which held on July 1 and then make the mapping of voting results that are based on religious identity.

The ethnic factor in Hein Namotemo's winner is still tangent to ethnic voting, where the majority of North Halmahera people inhabited by ethnic Tobelo-Galela still vote for their ethnic leaders. Certainly these voters vote on ethnic grounds because they believe that candidates "they" will further advance their lives and become patrons for them. Next we see how with Abdul Gani Kasuba who can 
not win in North Halmahera which is none other than its own ethnic origin, that is ethnic Galela. Abdul Gani Kasuba is one of the sons of North Halmahera region originating from ethnic Galela, an ethnic resident in a sub-district of the same name, Galela. Abdul Gani Kasuba's social background as the current Vice Governor made him rarely in his own hometown. Hein Namotemo's victory overcame Abdul Gani Kasuba, both of whom are from the same region due to the strong religious identity factor in North Halmahera. Informant's opinion above then the author formalized into the theory of secularization. In secularization theory by Peter L. Berger stated that the development of science and bureaucratic specialization are some of the factors that reduce religion as an influential political force, Hein Namotemo who is also the Regent of Halmahera Utara is able to realize Berger's secularization theory by reducing religion in its bureaucratic specialty thus producing an influential political force. In further explanation, Religion is something that can not be separated from our social life even able to influence the political power. Religion has a unique position to generate social capital because of two reasons. First, religious organizations (in this case like the Christian Church of Tobelo and so on) have long existed, connecting people to people and encouraging them to meet regularly. Secondly, religion in general promotes the soul of sukrela to give time and money to accomplish things. Religion has a strong potential for creating social action because the organization to direct people is 
13. available and religion has the power to motivate people and put them in a frame of mind suitable for collective action.

\section{CONCLUSION}

Identity politics mapping that occurred in the North Maluku elections in 2013 is based on ethnic identity and religious identity. At this first mapping, the ethnic identity of each candidate mobilizes a political force that strongly reflects the ethnic identity of the candidate. So that ethnic voting can be found in this study, voters choose candidates based on their ethnicity. On the second mapping, ie religious mapping. Religious identity becomes a factor that can raise political power in an election. Even the religious identity of the candidate head of the region becomes the determining factor of political power especially in provinces that have only one religious majority.

The North Maluku Election shows that the mapping of identity politics with ethnic and religious backgrounds is a tool of manipulation-a tool of strength-building. The number of candidates competing against different ethnic backgrounds resulted in ethnic voting. The ethnic differences presented in competing regional heads make each ethnic group trying to excel by gathering its political power using ethnic identity and religious identity. North Maluku, which is predominantly Muslim, in the elections in 2013 has one candidate keala region that is catholic. This leads to elections based on religious 
background, and religious identity becomes a force that can muster electoral votes, but only in certain areas.

\section{REFERENCES}

Budiardjo, M iriam. Dasar-Dasar Ilmu Politik. Jakarta : Gramedia Pustaka Utama. 2010

Bungin, Burhan, Analisis Data Penelitian Kualitatif. PT. Raja Grafindo Persada, Jakarta, 2003.

Haboddin, Muhtar, Menguatnya Politik Identitas di Ranah Lokal-Jurnal Studi Pemerintahan, volume 3. Brawijaya Pers, Malang, 2012.

Harris, Syamsuddin, Indonesia di Ambang Perpecahan.

Erlangga, Jakarta, 1999.

Hidayah, Zulyani, Ensiklopedi Suku Bangsa di Indonesia. LP3ES, Jakarta, 1996.

Ishiyama, John T. \& Marijke Breuning, IImu Politik dalam Paradigma Abad kedua puluh satu sebuah referensi panduan Tematis,Jilid 1. Kencana Prenada M edia Group, Jakarta 2013.

Kacung, Marijan Prof., Sistem Politik Indonesia : Konsolidasi Demokrasi Pasca Orde Baru. Kencana Prenada Media Group, Jakarta, 2013.

Laode, M.D., Etnis Cina Indonesia dalam Politik ; Politik Etnis

Cina Pontianak dan Singkawang di Era Reformasi 19982008. Yayasan Pustaka Obor Indonesia, Jakarta, 2012. 
136 Meteray, Bernarda, Nasionalisme Ganda Orang Papua. PT.

KOM PAS M edia Nusantara, Jakarta, 2012.

Moleong, Lexy J., Metode Penelitian Kualitatif. PT. Remaja

Rosdakarya, Bandung, 2004.

Sofyan,M . Daud, Ternate Mozaik Kota Pusaka, Genta

M ediapublika Pemerintah Kota Ternate, Ternate, 2013.

Soeseno, Nuri, Kewarganegaraan : Tafsir, Tradisi dan Isu-isu

Kontemporer. Perpustakaan Nasional RI Katalog Dalam

Terbitan (KDT), Depok, 2010.

Syafii, Ahmad Maarif, Politik Identitas dan Masa Depan

Pluralisme Kita. Yayasan Abad Demokrasi, Jakarta, 2012.

Syahrir, Andi Makkuradde, SH., Pemilukada M akassar 2008:

Sebuah Testimoni Demokrasi. PT. Fajar M akassar Grafika, Makassar, 2008.

Media Internet

antaranews.com/berita/383012/isi-hidayat-mus-raih-suara-

terbanyak-di-pilkada- malut. (diakses pada hari Rabu 3 Juli

2013, pukul 23.15 wita).

isuu.com/malutpost/docs/malut_post_08_april_2013. (di akses

pada hari Rabu 3 Juli 2013, pukul 23.45 wita)

kompasmedia.com/Enam-Pasang-Bertarung-di-Pilkada-M alukuUtara.htm (di akses pada Rabu 3 Juli 2013, pukul 23.48 wita). 